\title{
UM CORAÇÃO \\ QUE PULSA \\ FORA DO CORPO: \\ IMAGENS PASSIONAIS \\ NAS CARTAS \\ DE FRIDA KAHLO
}

\section{UN CORAZÓN QUE LATE FUERA DEL CUERPO: IMÁGENES PASIONALES EN LAS CARTAS DE FRIDA KAHLO}

\author{
A HEART THAT BEATS ON THE OUTSIDE: PASSIONATE IMAGES IN FRIDA KHALO`S \\ LETTERS
}

\author{
Maria da Penha Casado Alves* \\ William Brenno dos Santos Oliveira** \\ Universidade Federal do Rio Grande do Norte
}

\begin{abstract}
RESUMO: Entre os anos 30 e 40 do século passado, o México viu surgir, das cinzas da revolução mexicana, uma figura singular. Frida Kahlo é descrita, até hoje, pelo imaginário social - em seus quadros, em suas fotografias - como uma mulher que marcou uma época e que se tornou símbolo de lutas, e isso se estende até a contemporaneidade. Criaram-se, em volta da pintora mexicana, várias imagens sociais que eram delineadas no jogo dialógico entre suas obras e seus interlocutores. Tomando como referência essas assertivas, o artigo, ora apresentado, objetiva realizar análise de uma carta escrita por Frida para um de seus interlocutores amados/amantes - um dos homens com quem ela se envolveu, afetivamente, durante períodos diferentes de sua vida -, e mapear os ethé construídos por ela em enunciados nos quais ela 'pinta' verbalmente uma imagem de si, que se revela nas escolhas lexicais empreendidas para falar de amor, de traição, de amizade, de dor e de seu estar no mundo. Diante disso, refinamos uma imagem estética e ideológica de Frida Kahlo que se recobre de passionalidades distintas e de graus dialógicos diversos. Para tanto, fundamenta nossa análise os pressupostos teóricos advindos de M. Bakhtin, sobre estilo e enunciado concreto, e de Maingueneau, sobre ethos discursivo no que concerne à construção da imagem de si.
\end{abstract}

PALAVRAS-CHAVE: Frida Kahlo. Cartas pessoais. Ethos discursivo. Estilo. Enunciado concreto.

\footnotetext{
* Doutora em Comunicação e Semiótica pela PUC-SP. Pós-doutorado pela Unicamp. Professora Associada do Departamentode LetrasedaPós-Graduaçãoem EstudosdaLinguagem/UFRN. E-mail: penhalves@msn.com.

** Mestre em Linguística Aplicada pela Universidade Federal do Rio Grande do Norte. Professor substituto do Departamentode Letras da UFRN. E-mail: william_brenno@hotmail.com
} 
RESUMEN: Entre los años 30 y 40 del siglo pasado, México vio surgir de las cenizas de la revolución mexicana, una figura singular. Frida Kahlo es descrita, hasta hoy, por el imaginario social - en sus cuadros, en sus fotografías - como una mujer que ha marcado una época y que se ha convertido en un símbolo de luchas, y esto se extiende hasta la contemporaneidad. Se ha creado en torno a la pintora mexicana, varias imágenes sociales que se describen en el juego dialógico entre sus obras y sus interlocutores. Teniendo por referencia estas afirmaciones, el articulo aquí propuesto busca realizar un análisis de una carta escrita por Frida a uno de sus interlocutores amados/amantes - uno de los hombres con los que estuvo involucrada, emocionalmente, durante diferentes períodos de su vida - y, como objetivo, hacer un mapeo de los ethé construidos por ella en enunciados en los cuales ella "pinta" verbalmente una imagen de sí misma que se revela en las opciones léxicas elegidas para hablar de amor, de traición, de amistad, de dolor y de su estar en el mundo. Por lo tanto, hemos refinado una imagen estética e ideológica de Frida Kahlo que se cubre de pasiones distintas y de diversos grados dialógicos. Con este fin, fundamentan nuestro análisis los presupuestos teóricos postulados por Bakhtin sobre estilo y enunciado concreto y de Maingueneau sobre ethos discursivo.

PALABRAS CLAVE: Frida Kahlo. Cartas personales. Ethos discursivo. Estilo. Enunciado concreto.

ABSTRACT: Between the years of 1930s and 1940, Mexico witnessed the emergence, from the Mexican revolution's ashes, a singular figure. Frida Khalo is described, even today, by the social imaginary - in her paintings and photographs - as an epoch-making woman who became s symbol of struggle, and that remains nowadays. Several social images were created based on the Mexican painter, outlined in the dialogic game between her work and her interlocutors. Taking these assertions as references, this article aims to analyze a letter written by Frida for one of her loved/lover interlocutors - one of the men with whom she got affectively involved during distinct periods of her life -, and to map the ethé built by her in statements in which she verbally "paints" an image of herself that reveals itself through the lexical choices elected for talking about love, betrayal, friendship, pain, and being in the world. We have refined an aesthetic and ideological image of Frida Khalo that is covered by distinct passion and by diverse dialogic degrees. In order to do so, our analysis is based on M. Bakhtin's the theoretical assumptions on the image construction itself, and Maingueneau on discursive ethos.

KEYWORDS: Frida Khalo. Personal letters. Discursive ethos. Style. Concrete enunciation.

\section{INTRODUÇÃO}

Amurallar el propio sufrimiento es arriesgarte a que te devore desde el interior. Frida Kahlo (1954)

Entre os anos 30 e 40 do século passado, o México viu surgir, das cinzas da revolução mexicana, uma figura singular. Frida Kahlo é descrita, até hoje, pelo imaginário social - em seus quadros, em suas fotografias - como uma mulher que marcou uma época e que se tornou símbolo de lutas; tal fato estende-se até a contemporaneidade. Criou-se, em volta da pintora mexicana, várias imagens sociais, que foram delineadas no jogo dialógico entre suas obras e seus interlocutores. Tomando como referência essas assertivas, $\mathrm{o}$ enfoque, ora apresentado nos limites deste artigo, tomou como procedimento realizar análise de uma carta escrita por Frida para um dos seus interlocutores amados/amantes - um homem com quem ela se envolveu afetivamente durante períodos diferentes de sua vida -, e, como objetivo, mapear os ethé ${ }^{1}$ construídos por ela em enunciados nos quais ela 'pinta' verbalmente uma imagem de si que se revela nas escolhas lexicais realizadas para falar de amor, de traição, de amizade, de dor e de seu estar no mundo. Diante disso, refinamos uma imagem estética e ideológica de Frida Kahlo que se recobre de passionalidades distintas e de graus dialógicos diversos. Há, no recorte temporal e axiológico que fizemos para este artigo, uma mulher de natureza amante/passional que transformou o amor em mote para seus embates com interlocutores com quem se envolveu afetivamente.

Interessa, portanto, a Frida escritora de inúmeras cartas, que foram produzidas ao longo de toda sua vida, para diversos interlocutores, dentre eles, o seu grande amor Diego Rivera, seus amigos, suas amigas e seu médico.

${ }^{1}$ Optamos, neste artigo, por não destacar com itálico os termos ethé e ethos, uma vez que tais concepções já se apresentam em uso corrente nas pesquisas e publicações no Brasil. 
Tais cartas são reveladoras de vários ethé que não podem ser visualizados apenas observando seus quadros. Nessas cartas, Frida mostra seus sentimentos mais profundos e toda revolta com sua condição física e a concepção de fidelidade que seu amado marido seguia, pois, segundo ele, "ser fiel era apenas mais um dos valores burgueses" (HERRERA, 2012, p. 55). Ao escrever, Frida usava de toda sua franqueza, empregando um vocabulário singular e marcado de afetividade para externar suas ideias e sentimentos.

Assim, especificamente, interessa-nos, no modo de organização do enunciado, aquilo que Bakhtin (2003) irá chamar de estilo individual. Na relação de constituição do enunciado com o mundo da vida, será primordial para a nossa pesquisa a noção de ethos discursivo, encabeçada pela análise do discurso. Dessa maneira, procuramos neste texto, com a finalidade de atingir os nossos objetivos, entrecruzar e fundir essas duas categorias (ethos discursivo e estilo individual). Em outras palavras, podemos dizer que apresenta, na construção da análise que fizemos, o estilo individual como suporte estruturante para a construção do ethos discursivo. Em decorrência disso, olhamos para os dizeres de Frida Kahlo na intenção de buscar e problematizar as imagens sociais, amparados por pistas estilísticas, que foram, ao longo do tempo, construindo e desconstruindo ideologicamente Frida.

Investigar e observar os escritos de Frida Kahlo, por meio das lentes da Linguística Aplicada, é uma demanda que, há algum tempo, buscamos consolidar. A fonte de empiria a partir da qual construímos nosso corpus é o livro intitulado "Cartas apaixonadas de Frida Kahlo”, compilado por Martha Zamora, uma pesquisadora cujo interesse é a vida da artista mexicana. Trata-se, portanto, de uma reunião de cartas pessoais que Frida escreveu durante toda sua vida, compondo um fascículo com mais de cinquenta cartas escritas em diferentes épocas de sua vida e com interlocutores os mais variados possíveis, remetentes que rodeavam a vida social da mulher que matinha o hábito de escrever cartas. Nosso objeto de análise, no entanto, é composto por uma carta que selecionamos de acordo com interesses específicos.

Em continuidade, interessa-nos, para início de discussão, a assertiva de Geraldi (2012)

Quem estuda a linguagem não está interessado nos "recortes" dos discursos, mas no enunciado completo, total, para cotejá-lo com outros enunciados fazendo emergirem mais vozes para uma penetração mais profunda no discurso, sem silenciar a voz que fala em benefício de um já dito que se repete constantemente (GERALDI, 2012. p. 27-28).

Trataremos a carta, portanto, como um enunciado concreto e inacabado. Dela emergem vozes que nos ajudarão, no embate dialógico com nosso olhar exotópico, a dar acabamento às imagens que a pintora constrói de si, agora, discursivamente. Interessanos ouvir a Frida que está em luta axiológica constante com seus outros e que é constituída nessa arena dialógica.

Constata-se que Frida Kahlo é, por um lado, conhecida, mundialmente, por seus quadros, os quais originam muitos trabalhos no campo das artes plásticas e da história da arte, com as telas da artista mexicana; por outro, há ainda uma demanda investigativa sobre sua produção escrita, o que nos leva a afirmar, diante disso, que Frida é pouco conhecida por sua produção escrita, de modo que a produção acadêmica voltada para os escritos dela é quase inexistente. Nesse sentido, vale ressaltar os artigos publicados de Casado Alves $(2010 ; 2012 a ; 2012 b)$ a partir de um enfoque teórico-metodológico bakhtiniano. No campo de investigação da Linguística Aplicada (LA), por exemplo, não foi identificado nenhum estudo em nível de pós-graduação: tal fato lança-nos para o desafio de construir conhecimento sobre a prática discursiva, tendo como objeto/foco a epistolografia de Frida. O nosso objeto de pesquisa, portanto, revela-se pouco comentado, menos ainda sob o enfoque teórico e metodológico no qual nos apoiamos, qual seja: a concepção dialógica de linguagem e, consequentemente, de sujeito (BAKHTIN, 2003; 2009). Para esse pensador, o sujeito, histórico e inacabado, é construído e constituído nos processos de interação verbal, interação que pressupõe sempre a relação com um outro, a qual não se reduz apenas ao seu interlocutor imediato.

Dessa maneira, por adotarmos o que postula Bakhtin (2003, p. 262) a respeito dos gêneros discursivos - como produzidos, reelaborados e estilizados nas práticas sociais e que cada esfera social elabora seus “tipos relativamente estáveis" -, entendemos que o gênero discursivo "carta pessoal" não se constitui de forma diferente. No caso de Frida, ela é esse sujeito histórico e inacabado que, em constante diálogo com seus outros, por meio das cartas, cria para si mesma determinadas imagens que serão interpretadas, lidas e refratadas por tantos outros que, dependendo do lugar em que estão, poderão observá-la de formas diferentes. Nesse sentido, 
propomo-nos a analisar a carta de Frida Kahlo, a partir do olhar exotópico (BAKHTIN, 2003), para tentar dar acabamento às imagens que a pintora/escritora construiu de si mesma.

Em decorrência, a prática de escrita de Frida - via gênero carta pessoal - interessa-nos por consistir em uma prática social de linguagem a partir da qual ela posicionava-se a respeito dos mais variados temas. Ademais, devido ao fato de a LA, segundo Moita Lopes (2006, p. 14), ser, principalmente, "[...] um modo de criar inteligibilidade sobre problemas sociais em que a linguagem tem um papel central" e, ainda, de acordo com Celani (2000, p.19), "a LA como área do conhecimento é vista hoje como articuladora de múltiplos domínios do saber, em diálogo constante com vários campos que têm preocupação com a linguagem”, entendemos que nossa proposta necessita do par de óculos "indisciplinar" (MOITA LOPES, 2009) da LA para prosseguir nesse caminho investigativo que escolhemos trilhar.

\section{AS CORES TEÓRICAS DE NOSSA PALETA DIVERSIFICADA}

Compreendemos que "O acontecimento da vida do texto, isto é, a sua verdadeira essência, sempre se desenvolve na fronteira de duas consciências, de dois sujeitos.” (BAKHTIN, 2003, p. 311). Isso reforça a nossa inquietação discursiva de querer ouvir várias vozes em todos os momentos desta investigação, selecionando aquelas que melhor servirem ao nosso propósito comunicativo.

Nesse sentido, subsidiamo-nos nas considerações do Círculo de Bakhtin para a criação de um todo integrado (arquitetônico) a respeito das cartas apaixonadas de Frida Kahlo.

\subsection{A CONCEPCÃO DIALÓGICA DE LINGUAGEM}

Para situar o contexto desta pesquisa assim como o objeto, demarcaremos a concepção de linguagem, na qual apoiamo-nos. Tratase de uma concepção sócio-histórica, situada e construída nas bases sociais do discurso. Portanto, pensamos a linguagem como interação social e discursiva, "constitutivamente dialógica”, construída pelo sujeito e que, também, o constrói.

Em “Para uma filosofia do Ato Responsável” (BAKHTIN, 2010) - livro que data do início da década de vinte do século passado -, a inquietação de Bakhtin com a linguagem aparece subordinada às suas reflexões sobre ética e filosofia. Observamos que, nesse texto, o filósofo da linguagem já a compreende como atividade concreta vinculada à dimensão da vida e entendida, portanto, como concreta. Ela carrega expressividade e atitudes valorativas dos sujeitos em relação ao seu objeto discursivo.

Nessa perspectiva, em "Estética da criação verbal" (BAKHTIN, 2003), mais precisamente no capítulo sobre os gêneros do discurso, encontramos uma reafirmação dessa concepção de linguagem. Ou seja, para Bakhtin, não dá para desconsiderar o mundo da vida, pois, aqui, ele compreende os gêneros discursivos como "correias de transmissão entre a história da sociedade e a história da linguagem" (BAKHTIN, 2003, p. 268).

Partindo disso, podemos afirmar que, baseados nessa perspectiva teórica, pensamos a linguagem constituindo o mundo social e os sujeitos que vivem nesse mundo, em relação a outros tantos sujeitos e em relação a si mesmos. Desse modo, foi preciso, para compreender essa difícil relação (sujeito e mundo), remeter à discussão que Bakhtin/Volochínov (2009) faz a respeito de linguagem, de infraestrutura e de superestrutura; assim como sobre as determinações ideológicas e as atitudes responsivas desses sujeitos em atividades da base econômica e social. Portanto,

Com efeito, a enunciação é o produto da interação de dois indivíduos socialmente organizados e, mesmo que não haja um interlocutor real, este pode ser substituído pelo representante médio do grupo social ao qual pertence o locutor. [...] Essa orientação da palavra em função do interlocutor tem uma importância muito grande. Na realidade, toda palavra comporta duas faces. [...] Ela constitui justamente o produto da interação do locutor e do ouvinte. Toda palavra serve de expressão a um em relação ao outro. Através da palavra, defino-me em relação ao outro, isto é, em última análise, em relação à coletividade. (BAKHTIN/VOLOCHÍNOV, 2009, p. 73). 
Dessa maneira, pretendemos contornar, dar cores discursivas a essa autora-criadora, com a finalidade de traçar o ethos dessa mulher que foi marcada pelas traições de seu esposo, mulher do profano que levou uma vida regada pelas revoluções, artes e figuras significativas da sociedade tanto mexicana quanto mundial da época. Em outras palavras, Frida é o outro que pretendemos definir rastreando as escolhas lexicais que a autora fez e, posteriormente, seremos definidos e revelados também pelas palavras que direcionarmos, que escrevermos e, até mesmo, que construirmos. Tudo isso se dá em função da busca incansável pela imagem valorada de uma mulher, que, até a atualidade, é referência de vida, de resistência e de luta política.

Por conseguinte, intentamos, aqui, problematizar a linguagem em enunciados construídos nas cartas pessoais da pintora, nas relações de Frida com seus outros, sendo esses enunciados circulantes nas esferas discursivas do "mundo da vida" da própria autora, que se posiciona em defesa de ideologias diversas.

Dessa forma, compreendemos que o ser humano é um ser de língua(gem). Essa característica, construída social, cultural e historicamente, nos diferencia de outros animais. É por meio desse sistema de signos que atuamos socialmente no "mundo da vida", como bem afirma Bakhtin (2003).

Em outras palavras, essa teia dialógica - e aqui nos referimos à noção teórica de dialogismo, encontrada nas formulações da Análise Dialógica do Discurso (ADD) - permite-nos alcançar os projetos discursivos que surgem diante da interação com um mundo que é semiotizado, carregado de valores e ideologias. Tais projetos ganharam sentido naquilo que Bakhtin vai chamar de "enunciado".

Diante disso, compreendemos que esses enunciados são corporificados em arcabouços culturais, por meio dos quais, pragmaticamente, bebemos, namoramos, compramos, brigamos, rimos, opinamos, ou seja, atuamos. A esse "corpo enunciativo", Bakhtin nomeia como "gênero do discurso".

Portanto, recorremos à concepção bakhtiniana de gêneros discursivos como construção sócio-histórica de sujeitos em interação, para melhor embasar nosso artigo. Ao definir o conceito, Bakhtin (2003, p. 261) enfatiza que "o emprego da língua efetua-se em forma de enunciados", e tais enunciados estão se realizando o tempo todo nos diversos campos da atividade humana, evidentemente, cada campo vai produzir seus "tipos relativamente estáveis de enunciados" (Bakhtin, 2003, p. 262), que são os gêneros do discurso.

Segundo o teórico, toda atividade humana está atrelada à utilização da linguagem, e tais atividades são multiformes, ou seja, as formas "típicas de enunciados" (BAKHTIN, 2003) são totalmente variáveis e se adequam aos campos de atuação, o que não contradiz a unidade nacional de uma língua.

A riqueza e a diversidade dos gêneros do discurso são infinitas porque são inesgotáveis as possibilidades da multiforme atividade humana e porque em cada campo dessa atividade é integral o repertório de gêneros do discurso, que cresce e se diferencia à medida que se desenvolve e se complexifica um determinado campo. (BAKHTIN, 2003, p. 262)

Posto isso, devemos colocar em evidência a grandiosa heterogeneidade dos gêneros do discurso, sejam orais sejam escritos, nos quais estão incluídos desde rápidos diálogos do cotidiano até o romance com inúmeras páginas ou volumes. Aparentemente, essa imensa heterogeneidade impossibilita um único plano de estudo para si, já que esse plano se apresenta com fracas marcas de heterogeneidade. Mas, o que nos interessa é que, para Bakhtin (2003), esses enunciados refletem e refratam as condições específicas e as finalidades de cada campo e, principalmente, caracterizam-se por sua construção composicional; por seu conteúdo - em outros termos, um tema específico e recorrente em dada esfera - e pelo estilo de linguagem, ou seja, as escolhas dos recursos lexicais, fraseológicos e gramaticais.

Bakhtin/Volochínov (2009, p. 128) também afirma que "o discurso escrito é de certa maneira parte integrante de uma discussão ideológica em grande escala: ele responde a alguma coisa, refuta, confirma, antecipa as respostas e objeções potenciais, procura 
apoio, etc.". Sendo assim, é preciso que haja, em qualquer atividade que envolva gênero do discurso do ponto de vista bakhtiniano, assim como a exposição de ideias e posicionamentos de maneira satisfatória, atingindo o objetivo esperado pelo autor e alcançando o seu leitor/interlocutor, um trabalho de elaboração permanente, fazendo com que o texto, ao fim de todo o processo, constitua-se em um ato de dizer que se dirige para um outro. Nas cartas de Frida, percebemos esse processo no que diz respeito às escolhas lexicais que variam de acordo com o interlocutor.

Nessa perspectiva, estamos compreendendo a carta pessoal como gênero discursivo que surge em uma relação de convívio cultural pertencente à esfera do convívio social da época que, em seu processo de formação, utiliza e reelabora uma diversidade de gêneros primários, ou seja, gêneros mais simples, para integrarem a sua composição. Nesse sentido, os gêneros que vão compor os secundários (complexos) transformam-se, ganhando assim um caráter específico, como afirma Bakhtin (2003, p. 319), "perdem o vínculo imediato com a realidade concreta e os enunciados reais alheios".

Assim, podemos afirmar que o gênero discursivo "carta pessoal", neste momento, organiza e expressa o discurso de Frida Kahlo de maneira tal que nos permite resgatar os seus posicionamentos axiológicos e mapear, por meio desse estilo particular de escrever da autora, uma imagem que ela pinta dessa vez com palavras. Vejamos a citação de Bakhtin:

As formas da língua e as formas típicas dos enunciados, isto é, os gêneros do discurso chegam a nossa experiência e à nossa consciência em conjunto e estreitamente vinculadas. Aprender a falar significa aprender a construir enunciados (porque falamos por enunciados e não por orações isoladas). Os gêneros do discurso organizam o nosso discurso quase da mesma forma que organizam as formas gramaticais (sintáticas). Nós aprendemos a moldar o nosso discurso em forma de gênero e, quando ouvimos o discurso alheio, já adivinhamos o seu gênero pelas primeiras palavras [...]. (BAKHTIN, 2003, p. 283)

Desse modo, todos os textos e enunciados estão materializados em algum gênero do discurso, que, como já mencionamos, não pode ser visto como tipos estáveis, mas como relativamente estáveis. Essa ressalva é importante, pois, quando se pensa que um gênero fixou seus elementos caracterizadores, os sujeitos reorganizam as características de acordo com seu horizonte social, ou seja, com as situações imediatas de enunciação como também com as situações mais amplas.

\subsection{O SUJEITO BAKHTINIANO}

Conforme discutido na seção anterior, interessa-nos a visão de sujeito que seja balizada pela construção social, histórica e cultural, seguindo o Círculo de Bakhtin. Não se pode pensar em sujeito desprendido de seu círculo social, desconsiderando sua história e as influências externas ao próprio sujeito, muito menos pensar a possibilidade de um sujeito acabado, pleno de sentido, sem espaços para os inacabamentos que são inerentes aos seres de linguagem. O sujeito bakhtininano é inacabado. Ele estará sempre no limiar do acabamento que o outro lhe dará. Em outras palavras, é o outro quem me define, quem me propicia o acabamento estético. Esse acabamento pode se modificar ao passo que esse outro, também, é modificado e acabado por seus interlocutores.

Se o espelho é o referente mais primário e o desejo - o olhar do outro - é o mais complexo, há entre ambos inúmeras maneiras pelas quais o corpo obtém notícia de si e encontra sua razão e seu sentido, como afirma Bakhtin (2003):

Contemplar a mim mesmo no espelho é um caso inteiramente específico de visão da minha imagem externa. Tudo indica que neste caso vemos a nós mesmos de forma imediata. Mas não é assim; permanecemos dentro de nós mesmos e vemos apenas o nosso reflexo, que não pode tornar-se elemento imediato da nossa visão e vivenciamento do mundo: vemos o reflexo de nossa imagem externamas não a nós mesmos em nossa imagem externa; a imagem externa não nos envolve ao todo, estamos diante e não dentro do espelho; o espelho só pode fornecer o material para a auto-objetivação, e ademais um material não genuíno. De fato, nossa situação diante do espelho sempre é meio falsa: como não dispomos de um enfoque de nós mesmos de fora, também nesse caso nos compenetramos de um outro possível e indefinido, com cuja ajuda tentamos encontrar uma posição axiológica em relação a nós mesmos; também aqui tentamos vivificar e enformar a nós mesmos a partir do outro. Daí a expressão original e antinatural de nosso rosto que vemos no espelho [e] que não temos na vida (BAKHTIN, 2003, p. 30). 
Assim acontece nas mais variadas esferas do mundo da vida e nas mais variadas atividades humanas que envolvam interação face a face, seja nas habilidades de brincadeira e do trabalho, seja nas nimiedades do ócio; no esporte e no espetáculo, praticados ou apenas presenciados; na roupa e nos detalhes infinitos do cuidado pessoal; no que se come e no que se excreta; nas reviravoltas do sexo; na coleção de fotos que o tempo vai juntando em uma caixa de sapatos; na literatura e na filosofia, na psicanálise, no conhecimento científico ou na arte. Em todo e qualquer campo em que os enunciados concretos circulem socialmente, seremos refletidos e refratados pelo acabamento que o outro nos dá.

Desse modo sendo, nos filiamos à noção de sujeito de Bakhtin e seu Círculo. Segundo o autor, para compreender esse "ser de verdade", é preciso observar sua construção social, a partir da interação verbal na relação com o outro. Ou seja, o sujeito bakhtiniano é ativo na constituição da língua e é constituído por ela. Obviamente, toda essa construção só pode acontecer a partir da interação verbal com o outro que lhe dará acabamento estético.

Acompanhada dessa noção de sujeito, associamos nossa pesquisa, também, ao conceito de alteridade que, assim como a concepção anterior, é discutida ao longo de toda obra de Bakhtin. Compreende-se, portanto, a alteridade como essa necessidade estética e, provavelmente, absoluta e constitutiva que o ser de linguagem tem do outro. Nesse sentido, o único que é capaz de criar uma imagem valorada, dar acabamento a esse sujeito é a relação eu-outro. Em outras palavras, só o outro teria como atribuir uma personalidade ao $e u$; sem esse outro, essa imagem externa simplesmente não existe.

Dessa forma, Bakhtin (2003. p.34) afirma:

De fato, só no outro indivíduo me é dado experimentar de forma viva, estética (e eticamente), convincente a
finitude humana, a materialidade empírica limitada. O outro me é todo dado no mundo exterior a mim como
elemento deste, inteiramente, limitado em termos espaciais; em cada momento dado eu vivencio nitidamente
todos os limites dele, abranjo-o por inteiro com o olhar e posso abarcá-lo todo com o tato; vejo a linha que lhe
contorna a cabeça sobre o fundo do mundo exterior, e todas as linhas do seu corpo que o limitam no mundo[...].

Diante disso, podemos afirmar que a maneira de vivenciarmos, como pesquisadores, leitores, admiradores, situados em um lugar específico, o eu de Frida Kahlo diferencia-se da maneira como experenciamos o nosso próprio eu. Isso, em linhas gerais, reforça a ideia de alteridade que está diretamente relacionada com a grande metáfora bakhtiniana: a relação interacional entre um eu e um outro.

\subsection{ESTILO E ETHOS DISCURSIVO}

Nossa investigação, como já explicitado, procura chão firme no entrecruzamento do ethos discursivo e do estilo individual. Nós colocamos em pauta as escolhas estilísticas de Frida Kahlo, em um contexto concreto, específico e delimitado historicamente, na tentativa de problematizar: primeiro, as escolhas estilísticas; segundo, onde, na materialidade linguística, estão situadas; terceiro, em que elas diferem de outras escolhas feitas, também, pela autora-criadora; e quarto, quais são os motivos que nos levam, por meio dessas escolhas, a gerar imagens axiológicas que perduram até os dias atuais.

Na tentativa de sustentarmos a investigação, resolvemos utilizar um cabedal teórico que se afinasse melhor com nossos objetivos. Ou seja, ao colocarmos, no bojo de nossa análise, os enunciados concretos, produzidos em situações reais no mundo da vida, e seus enunciadores, temos a intenção de nos apoiar na teoria bakhtiniana e em outras teorias que permitam uma abordagem enunciativa, assim como em perspectivas teóricas que contemplem a noção de ethos discursivo e de estilo individual, pois essas serão as categorias basilares deste artigo.

Para este artigo, a categoria estilo é deveras importante. Por isso, gostaríamos de dar o enfoque devido a essa categoria, pois ela está em um eixo teórico estruturante de nossa pesquisa. Sem ela, não teríamos como traçar o ethos discursivo, tendo em vista que ele é estruturado por indícios estilísticos, os quais embasarão nossas ideias a respeito das imagens ideológicas de Frida na carta em foco 
Por conseguinte, sabemos que, na contemporaneidade, é comum associar estilo a sujeito, falante, autor, enunciador, etc., mas nem sempre isso foi algo comum. Assim, o estilo, retirado da perspectiva retórica greco-latina, perde forças com o apagamento e, até mesmo, o esgarçamento do sujeito histórico nas teorias sobre a linguagem. Depois, quando as perspectivas enunciativas extrapolam uma abordagem mais estruturalista, esses elementos voltam para a cena nas discussões teóricas, principalmente, naquelas postulações nas quais o sujeito entra em cena com toda sua historicidade e encarnado concretamente por sua trajetória social.

No entanto, não traçaremos um percurso cronológico do estilo na história da construção do pensamento e das ciências linguísticas por não ser esse o escopo do presente artigo.

Interessa-nos a subjetividade na perspectiva enunciativa, que redimensiona toda discussão sobre estilo e nos faz ancorar no porto bakhtiniano, pois é Bakhtin quem melhor nos auxilia com a categoria estilo. O filósofo da linguagem tem, do ponto de vista teórico, a melhor definição de estilo para a nossa pesquisa, e ela se aglutina a outras noções que colocamos anteriormente: sujeito, gênero discursivo, exotopia, autoria, enunciado, etc. Como, em sua obra, todos os conceitos estão interligados, M. Bakhtin explica as características que compõem o estilo em detrimento das explicitações de outras categorias. Nesse dimensionamento, Bakhtin enfoca o estilo como característica do homem enquanto ser de linguagem, ser histórico, ser que se constrói na relação eu e o outro. Assim, para Volochínov (2013, p.87):

A palavra é uma espécie de "cenário" de certo acontecimento. A compreensão autêntica de um sentido global deve reproduzir este acontecimento da relação recíproca dos falantes, "representar-lhe" outra vez, e o que compreende adotar o papel de ouvinte. Porém para cumprir com este papel deve compreender claramente também as posições de outros participantes.

M. Bakhtin, em vários momentos, discute a noção de estilo como categoria essencial na construção do gênero discursivo. Tal arcabouço teórico nos dá suporte para compreender estilo como acabamento estético. Portanto, o estilo, para a teoria bakhtiniana, está intimamente ligado à composição e ao tema de um texto, haja vista que é no estudo das formas e das categorias que encontramos o estilo.

Assim sendo, por se tratar de uma categoria essencialmente interlocutiva e dialógica, o estilo de um determinado texto e a maneira singular com que um enunciador faz uso dessa categoria, a qual, para Bakhtin (2003), nunca esteve divorciada de definições ideológicas, possibilitam, ao sujeito produtor, deixar as marcas de subjetividade em todo o plano da materialidade linguística. Dessa forma, o estilo traz consigo a avaliação do enunciador e uma concordância valorativa com o coenunciador. Em outras palavras, podemos afirmar que, para esse pensador, a noção teórica de estilo está relacionada a um querer dizer do enunciador, que ganha forma, que define seus limites sob as condições de interlocução. Trata-se, portanto, de um acabamento que é estético e transitório, sempre aberto a novos sentidos por estar submetido às condições sócio-históricas.

Ademais, para elucidar essa questão, trazemos a voz do próprio M. Bakhtin. Chamamos atenção para a definição do estilo para o autor. Nesse sentido, ele assevera:

A relação orgânica e indissolúvel do estilo com o gênero se revela nitidamente também na questão dos estilos de linguagem ou funcionais. No fundo, os estilos de linguagem ou funcionais não são outra coisa senão estilos de gênero de determinadas esferas da atividade humana e da comunicação. (BAKHTIN, 2003, p.266).

E complementa:

Uma determinada função (científica, técnica, publicística, oficial, cotidiana) e determinadas condições de comunicação discursiva, específicas de cada campo, geram determinados gêneros, isto é determinados tipos de enunciados estilísticos, temáticos e composicionais relativamente estáveis. O estilo é indissociável de determinadas unidades temáticas e - o que é de especial importância - de determinadas unidades composicionais: de determinados tipos de construção do conjunto, de tipos do seu acabamento, de tipos da relação do falante com outros participantes da comunicação discursiva - com os ouvintes, os leitores, os parceiros, o discurso do outro, etc. O estilo integra a unidade de gênero do enunciado como seu elemento. Isto 
não significa, evidentemente, que o estilo de linguagem não possa se tornar objeto de um estudo especial independente. (BAKHTIN, 2003, p. 266)

No que diz respeito a essa vinculação entre estilo e gênero, podemos afirmar que não há estilo fora de um gênero ou de um enunciado. É preciso, no entanto, levar em conta, para um estudo amparado pelas vozes bakhtinianas que versam sobre estilo, que as condições de interlocução incluem, também, as definições de estilo individual e estilo de gênero, que impõem certas restrições ao querer dizer do enunciador e à forma como esse querer dizer se manifesta. Sobre o conceito de estilo, Brait afirma:

Focalizado sob uma dimensão bastante especial, diferenciada, coerente com a 'teoria dialógica' como um todo, estilo se apresenta como um dos conceitos centrais para se perceber, a contrapelo, o que significa, no conjunto das reflexões bakhtinianas, dialogismo, ou seja, esse elemento constitutivo da linguagem, esse princípio que rege a produção e a compreensão dos sentidos, essa fronteira em que eu/outro se interdefinem, se interpenetram, sem se fundirem ou se confundirem. (BRAIT, 2010, p.80)

Dessa forma, este artigo escolhe a teoria bakhtiniana para amparar as análises no que diz respeito ao estilo porque acreditamos que as escolhas não são feitas de modo aleatório pelos sujeitos produtores. Elas, na realidade, respondem eticamente às formações culturais, familiares, religiosas, políticas, acadêmicas, dentre outras, que esses sujeitos vão recebendo ao longo de suas vidas. Com Frida não seria diferente. Escolhemos essa noção de estilo porque não enxergamos, nas cartas da pintora mexicana, apenas lexemas ou classes gramaticais espalhadas sobre o papel. As palavras selecionadas por Frida surgem recobertas por unidades melódicas e axiológicas que vão revelando suas intenções e construindo seu ethos. E, como afirma V. Volochínov:

Acima de tudo, as valorações determinam a seleção das palavras pelo autor e a percepção desta seleção (coeleição) pelo ouvinte. Porque o poeta não escolhe suas palavras de um dicionário, mas do contexto da vida no qual as palavras se sedimentam e se impregnam de valorações. Deste modo, escolhe as valorações relacionadas com as palavras, e, além disso, desde o ponto de vista dos portadores encarnados destas valorações. Pode-se dizer que o poeta trabalha todo tempo com a aprovação ou desaprovação, ou a discordância do ouvinte. Ademais, a valoração é ativa também com relação ao objeto da enunciação, que é o herói (protagonista). (VOLOCHÍNOV, 2013, p. 88)

Em outras palavras, esse estilo individual representa a expressividade própria dos sujeitos no jogo dialógico. Portanto, se o enunciado é reflexo da individualidade de quem o produz - seja oral, verbal ou verbo-visual -, as marcas do estilo desses sujeitos estarão sempre presentes, revelando posicionamentos ideológicos.

No que concerne à imagem de si construída nos textos escritos, consideramos que a noção de ethos discursivo, em consonância com essa visão de sujeito bakhtininiano, permiti-nos compreender como o eu constrói uma imagem de si no entrecruzamento de olhares (seu e de outros), uma vez que ninguém tem uma visão de si mesmo em total acabamento. A noção de ethos interessa, ultimamente, às mais variadas áreas das ciências humanas, especialmente, àquelas que estudam o discurso. Nascida em solo grego, com Aristóteles como principal referência em seu estudo, a noção de ethos hoje tem estudiosos da análise do discurso (em diferentes perspectivas) que a entendem como constituinte e constituidora do ato de enunciação. Maingueneau (2008) esclarece que não se deve desconsiderar o fato de que o público constrói representações do ethos do enunciador antes mesmo que este fale. Ademais, o ethos é uma noção discursiva que se constrói por meio do (e no) discurso. O ethos é, fundamentalmente, um processo interativo de influência sobre o outro; é uma noção híbrida (sócio-discursiva), um comportamento socialmente avaliado, que não tem como ser avaliado fora de uma situação de interação. São as postulações teóricas sobre ethos discursivo advindas de Mainguenau (2008; 2005; 2006) que atendem, portanto, ao que ora nos propomos a investigar.

$\mathrm{Na}$ carta selecionada para este artigo, percebemos a presença de rastros de estilo ou escolhas lexicais que dão o tom, a forma e o modo com os quais, na arquitetônica dos enunciados/cartas, Frida constrói uma imagem de si. Mesmo que essa imagem axiológica não corresponda àquilo que realmente ela pretendia. Trata-se, portanto, do ethos que ela, ao fazer determinadas escolhas, constrói. Verdadeiro ou não, correspondente à realidade ou não. 
Subdividimos, desse modo, as categorias que obtivemos diante da observação do corpus e, após submeter a carta/enunciado ao crivo de nosso olhar exotópico, obtivemos as categorias que elencamos e que ora apresentamos: (1) vocativos: o enquadramento que Frida dá ao outro; (2) perguntas retóricas: apenas do jogo interlocutivo? Uma Frida que pede para ser amada; (3) adjetivações de si; (4) metáforas.

Por fim, analisaremos a carta, considerando o anteriormente exposto.

\section{O QUE DIZEM OS ENUNCIADOS...}

Enunciado

Imagem: carta de 1938

8 de Diciembre de 1938

Niño mío...

Son las seis de la mañana

y los guajolotes cantan,

calor de humana ternura

Soledad acompañada

Jamás en toda la vida

olvidaré tu presencia

Me acogiste destrozada

y me devolviste entera

Sobre esta pequeña tierra

¿dónde pondré la mirada?

¡Tan inmensa, tan profunda!

Ya no hay tiempo, ya no hay nada.

Distancia. Hay ya sólo realidad

¡Lo que fue, fue para siempre!

Lo que son las raíces

que se asoman transparentes

transformadas

En el árbol frutal eterno

Tus frutas dan sus aromas

tus flores dan su color creciendo con la alegría

de los vientos y la flor

No dejes que le dé sed

al árbol del que eres sol,

que atesoró tu semilla

Es "Diego" nombre de amor.

De la gran ocultadora

Frieda

Fonte: Zamora (1997) 
Iniciaremos nossa análise atentando para a estrutura composicional dessa carta. Considerando isso e recorrendo aos traços discursivos que caracterizam esse texto como representativo do gênero carta pessoal, podemos afirmar que Frida rompe com o estilo funcional do gênero e constrói todo o enunciado transgredindo a "ordem" no que tange à macroestrutura. O que, a princípio, já singulariza a escrita da autora e ensaia uma transgressão recorrente da passionalidade fridiana.

No enunciado em questão, vemos uma construção atípica. E é por acreditarmos na influência do conteúdo temático sobre as escolhas de Frida nesse enunciado que há a presença de um vocativo valorado. Sabemos que o motivo que levou a pintora mexicana a produzir o enunciado tem uma carga emocional específica.

Neste enunciado, Frida evoca Diego da seguinte maneira: L3 Niño mío... Nessa cenografia, o vocativo dá vez e voz a uma Frida que se dirige ao maior amor de sua vida. A utilização do possesivo mío é uma marca recorrente que a acompanha também em outras missivas amorosas para outros interlocutores. No entanto, temos a introdução de um elemento fulcral na composição desse vocativo, que nada mais é do que o substantivo Niño servindo como adjetivo.

Em outras palavras há um acabamento dado a Diego que o coloca como a criança de Frida. Mais uma vez, o ser amado vira objeto de pertencimento. Mas, agora, Frida transforma o Sapo-gordo (como era nomeado socialmente) em um menino amado. Com esse vocativo, Frida preenche, com o amor que sentia por Diego, a lacuna existente em seu lado materno, pois não podia ter filhos por causa do acidente que dilacerara sua coluna, sentindo-se incompleta com isso. Não é a toa que a autora o nomeia assim, especialmente, nessa carta-enunciado.

Desta feita, não nos é difícil afirmar que a intensidade que há no comportamento passional de Frida com relação a Diego é muito maior em relação aos outros interlocutores que compõem o recorte deste corpus.

Consideramos, também, as escolhas estilísticas no âmbito da organização composicional, como, por exemplo, a disposição em versos diante de um parâmetro pré-definido. Tal composição se encontra compactada em uma única estrofe de vinte e cinco versos. Frida compõe esse enunciado/carta escolhendo versos que vão desde hexassílabos até versos bárbaros. Dessa forma, podemos afirmar que Frida nunca teve a intenção de responder aos modelos canônicos no que diz respeito à tradição lírica.

Essa forma de organizar poeticamente e de colocar o texto em verso em um gênero prototipicamente escrito em prosa, demonstra a plasticidade dos escritos fridianos, assim como sua ousadia de transgredir. Essa é uma marca recorrente nas construções das cartas de Frida. Possivelmente, tais escolhas assinalam uma escrita que brinca com as possibilidades da linguagem, a fim de dar concretude ao seu projeto de dizer. Ainda nesse enunciado, temos uma vasta recorrência de metáforas que vão se compondo a partir do jogo criativo que Frida, agora mulher adulta, faz com as adjetivações.

Ela rompe com a forma composicional, com a modalidade escrita em verso e escreve uma carta/poema, ou um enunciado lírico, que dá vazão a um ethos passional mais intenso, mais sensível e, agora, erudito. A carta é plasmada em um registro tido como culto na modalidade escrita da língua e, convencionalmente, poético. Nesse aspecto, podemos estabelecer uma relação, com as devidas ressalvas a contextos de produção e aos sujeitos que ali se constituíam, entre essa carta/poema e a poesia marginal brasileira (década de 1970), ou da geração de 1930 - primeira geração genuinamente modernista -, que quebrou com uma métrica parnasiana, mais fechada.

A metáfora que se inicia em $L 7$ faz remissão à presença do próprio Diego na vida de Frida. No contrapeso dos dois substantivos abstratos (calor e ternura), estabelece-se um par dicotômico que acaba criando a metáfora em si. Frida humaniza o calor da presença marcante de seu amado.

Seguindo essa mesma ordem de inversão, teremos, logo em seguida no verso $\boldsymbol{L} \boldsymbol{8}$, a utilização de mais uma metáfora de antagonismos (Soledad acompanhada). Como pode existir uma solidão acompanhada? Essa construção metafórica remete-nos ao sentir de Frida, pois, mesmo estando rodeada de amigos e de boas companhias na França, onde expunha seus afrescos, nada preenchia o vazio e a solidão causados pela falta de Diego.

Alves \& Oliveira $/$ Um coração que pulsa fora do corpo: imagens passionais nas cartas de Frida Kahlo 
Por conseguinte, temos o xeque-mate dessa construção metafórica nos versos $\boldsymbol{L} \mathbf{1} \boldsymbol{1}$ e $\mathbf{L 1 2}$, pois, neles, Frida enaltece a importância de seu amado, uma vez que ele fora o responsável por sua reconstrução. Muito provavelmente, Frida, quando usa o adjetivo $\mathbf{L 1 1}$ "destrozada”, refere-se às sequelas deixadas pelo acidente que ela sofreu ainda na juventude. Diego, então, teria sido o responsável pela vontade de reconstrução que impregnara a alma de Frida.

A terceira e última grande metáfora que Frida constrói nessa carta gira em torno da árvore, ou melhor dizendo árbol. Esta se inicia no verso $\mathbf{L} 15$ e se espraia até o verso L28. Aqui a autora-criadora usa a árvore para dialogar com o discurso bíblico da origem do homem e o fato de este ter comido o fruto proibido na árvore da sabedoria: $\mathbf{L 2 2}$ En el árbol frutal eterno. Essa seria a responsável pela vida e pela sabedoria do Éden, por outro lado foi proibida no mito adâmico. Frida, ao nosso ver, estabelece relações dialógicas com a tradição bíblica, porque acreditamos que esta é uma maneira de, metaforicamente, referir-se a Diego como aquele que lhe dá vida, ou, até mesmo, ao que é proibido, pecado, mas que a seduz com forças irracionais.

No desdobramento da metáfora em questão, a autora faz uso de palavras do mesmo campo lexical que remeterão à árvore: $L 19$ las raíces; $\boldsymbol{L} 23$ Tus frutas dan sus aromas; $\boldsymbol{L} 24$ tus flores dan su color; $\boldsymbol{L} 25$ la flor; $\boldsymbol{L} 28$ que atesoró tu semilla. E, ainda, assevera a força e a imensidão desta árvore que representa seu amor por Diego: $\mathbf{L} 15$ ¡Tan inmensa, tan profunda!. Tais escolhas podem remeter, ainda, à relação visceral que Frida tinha com a natureza e que se presentificou em vários de seus quadros.

Em sendo assim, podemos constatar que há, recorrentemente, nesse enunciado, a presença de uma passionalidade mais intensa e desesperada, uma tendência por conclamação ao amor do outro e, em tons quase jocosos, uma autocomiseração que a coloca no patamar de sofrimento dilacerante. Frida Kahlo consome e é consumida por essa intensa passionalidade. Não há controle sobre o amor que a autora sente por Diego e isso está marcado nas escolhas lexicais que ela faz recorrentemente, tanto no campo do conteúdo quanto no campo da forma.

\section{CONSIDERAÇÕES FINAIS}

O artigo, que ora se conclui em seu inevitável inacabamento, pôs em foco a escrita de Frida Kahlo e a construção de um ethos discursivo marcado pela passionalidade e o amor visceral que a pintora alimentava por Diego Rivera. Conhecida mundialmente por suas telas, a escritora manteve em vida uma prática discursiva em que a linguagem verbal se materializava em cartas e em um diário, os quais nos deixam ver outra Frida, enredada em palavras, construindo um estilo que a singulariza, tanto quanto as cores de suas telas. A mulher revelada na prática epistolográfica consolida um ethos marcado pela paixão, pelo amor irremediável por Diego e pela vida. Sobre uma dessas cartas, tratou o presente artigo que se coloca como mais uma resposta a uma vasta produção que demanda pesquisa, abordagens e investigação sobre a produção de uma artista que ocupa um lugar na história como sujeito que nos interpela para construir conhecimento sobre sua obra.

\section{REFERÊNCIAS}

AMOSSY, R. Da noção retórica de ethos à análise do discurso. In: AMOSSY, R. (Org.). Imagens de si no discurso: a construção do ethos. São Paulo: Contexto, 2005. p. 9-28.

BAKHTIN, M. Estética da criação verbal. 5. ed. São Paulo: Editora WMF Martins Fontes, 2003. . Para uma filosofia do ato responsável. São Carlos/SP: Pedro \& João Editores, 2010.

Palavra própria e palavra outra na sintaxe da enunciação. São Carlos/SP: Pedro \& João Editores, 2011. 
BAKHTIN, M. M./VOLOCHINOV, V. N. Marxismo e filosofia da linguagem: problemas fundamentais do método sociológico na ciência da linguagem. 12. ed. São Paulo: Hucitec, 2009.

CASADO ALVES, M. P. Frida Kahlo: quando a arte e a vida não se separam. In: Grupo de Estudos dos Gêneros do Discurso (GeGe) - UFSCAR. Círculo - rodas de conversa bakhtiniana: caderno de textos e anotações. São Carlos/SP: Pedro e João Editores, 2010. p. 219-221.

Ethos e exotopia do olhar: as Cartas Apaixonadas de Frida Kahlo. In: UYENO, E. Y.; PUZZO, M. B.; RENDA, V. L. B. de S. (Org.). Linguística aplicada, linguística e literatura: intersecções profícuas. Campinas/SP: Pontes Editores, 2012a, v. 1. p. 30-47.

Frida Kahlo entre palavras e imagens: a escrita diarista e o acabamento estético. Revista Linha D’água, São Paulo, v. 25, n. 2, p. 169-184, 2012b.

CELANI, M. A. A.; Relevância da Linguística Aplicada na Formulação de uma Política Educacional Brasileira. In: FORTKAMP, M. B. M.; TOMITCHI, L. M. (Org.). Aspectos da Linguística Aplicada: estudos em homenagem ao professor Hilário Inácio Bohn. Florianópolis: Insular, 2000. p. 17 - 32.

CHARAUDEAU, P. Discurso político. São Paulo: Contexto, 2006.

FARACO, C. A. Linguagem e diálogo: As idéias lingüísticas do Círculo de Bakhtin. São Paulo: Parábola Editorial, 2009.

GERALDI, J. W. Heterocientificidade nos estudos linguísticos. In: Grupo de Estudos dos Gêneros do Discurso (GeGe) - UFSCAR. Palavras e contrapalavras: enfrentando questões da teoria bakhtiniana. São Carlos/SP: Pedro \& João Editores, 2012 . p. 19 - 39.

GRILLO, R. Dominant language. Cambridge: Cambridge University Press, 1988.

HERRERA, H.. Frida: a biografia. Trad. R. Marques. São Paulo: Globo, 2011.

MAINGUENEAU, D. A propósito do ethos. In: MOTTA, A.R; SALGADO, L. (Org.). Ethos discursivo. São Paulo: Contexto, 2008. p. 11-32.

Ethos, cenografia, incorporação. In: AMOSSY, R. (Org.). Imagens de si no discurso: a construção do ethos. São Paulo: Contexto, 2005.

Discurso literário. São Paulo: Contexto, 2006.

MOITA LOPES, L. P. da. (Org.) Uma linguística aplicada mestiça e ideológica: interrogando o campo como linguista aplicado. In: Por uma linguísticas aplicada INdisciplinar. São Paulo: Parábola Editorial, 2006. p. 14.

VOLOCHÍNOV, V. N. A construção da enunciação e outros ensaios. São Carlos/SP: Pedro\& João Editores, 2013.

ZAMORA, M. (Comp.). Cartas apaixonadas de Frida Kahlo. Tradução Vera Ribeiro. 3 ed. Rio de Janeiro: José Olympio, 1997. 